\title{
APLIKASI MACAM PUPUK MAJEMUK DAN MULSA TERHADAP PENINGKATAN PRODUKSI CABAI RAWIT (Capsicum frutescens $L$.)
}

\section{APPLICATIONS OF ADVANCED FERTILIZER AND MULSE FOR INCREASING PRODUCTION OF RAWIT CHILI (Capsicum frutescens L.)}

\author{
Muhammad Annas Ayyubi, Ir Choirul Anam, dan Mariyatul Qibtiyah \\ Fakultas Pertanian Universitas Islam Darul Ulum Lamongan \\ Korespondensi : abi049239@gmail.com
}

\begin{abstract}
ABSTRAK
Tanaman cabai rawit ialah salah satu macam sayuran Hortikultura penting yang bernilai tinggi dan cocok di budidaykan di daerah tropika seperti di Indonesia. Hal ini menunjukkan bahwa cabai rawit sangatlah di butuhkan di masyarakat untuk kebutuhan sehari-hari. Mengingat sangat di perlukaannya komoditas tanaman cabai rawit di masyarakat sebagai salah satu bumbu makanan pokok. Maka perlu adanya upaya untuk meningkatkan produksi tanaman cabai rawit. Salah satu upaya tersebut dengan menggunakan pupuk majemuk dan mulsa organik. Penelitian ini bertempat di Desa Tunggul, Kecamatan Paciran, Kabupaten lamongan dengan ketinggian tempat \pm 5 Meter dpl. Waktu penelitian dilaksanakan pada bulan Pebruari sampai bulan Mei 2020. Penelitian ini menggunakan metode Rancangan Acak Kelompok (RAK) faktorial yang trediri dari 2 factor dan setiap faktor terdiridari 3 level yang diulang 3 kali ulangan, yaitu :Faktor pertama macam pupuk majemuk terdiri dari 3 taraf yaitu : Tanpa Pupuk Majemuk (kontrol), Pupuk NPK Mutiara, PupukKandang. faktor kedua mulsa terdiridari 3 taraf yaitu: Tanpa mulsa (Kontrol),mulsa jerami, mulsa skam. Pengamatan produksi tanaman cabai rawit meliputi fase vegetatif (Tinggi Tanaman, Jumlah Cabang, Diameter Batang dan fase generatif (jumlah buah pertanaman, Berat Buah per Tanaman). Hasil penelitian menunjukkan interaksi antara perlakuan pupuk majemuk NPK dan mulsa organik jerami berpengaruh baik pada semua parameter pengamatan.
\end{abstract}

Kata kunci: Cabai Rawit, Mulsa Jerami, Pupuk Majemuk

\begin{abstract}
The cayenne pepper plant was one of the important horticultural vegetables that were of high value and suitable for cultivation in tropical regions such as Indonesia. This showed that cayenne pepper was need in the community for their daily needed. Given the great pain of the cayenne pepper plant commodity in the community as one of the staple food spices. So there needs to be an effort to increase the production of cayenne pepper. One such effort was by using compound fertilizers and organic mulch. This research took place in Tunggul Village, Paciran District, Lamongan Regency with an altitude of $\neg \pm 5$ meters above sea level. The research was carried out in February to May 2020. This research used a factorial randomized block design (RBD) method consisting of 2 factors and each factor consisting of 3 levels repeated 3 times, namely: The first factor was a type of compound fertilizer consisting of 3 levels namely: Without Compound Fertilizer (control), Pearl NPK Fertilizer, Manure Fertilizer. The second factor consists of 3 levels of mulch, namely: No mulch (Control), straw mulch, skam mulch. Observations of cayenne pepper production include the vegetative phase (Plant Height, Number of Branches, Stem Diameter and generative phase (number of fruits per plant, Fruit Weight per plant). The result showed that the interaction between NPK compound fertilizer treatment and organic straw mulch had a good effect on all observation parameters. .
\end{abstract}


Keywords: Compound Fertilizer, Straw Mulch, Cayenne Pepper

\section{PENDAHULUAN}

Tanaman cabairawit (Capsicum frutescens L.) berasal dari daratan benua Amerika, tepatnya di Amerika Latin. Cabai rawit yang dulunya adalah tanaman liar yang disebar oleh burung (cabai burung) dan mempunyai nama ilmiah Capsicum frutesncens L. Karena ukuran buahnya yang kecil, di Indonesia cabai ini dikenal dengan nama cabai rawit (Setiadi, 2007).

Mengingat sangat di perlukaannya komoditas tanaman cabai rawit di masyarakat sebagai salah satu bahan makanan pokok. Maka perlu adanya upaya untuk meningkatkan produksi tanaman cabai rawit. Salah satu upaya tersebut dengan menggunakan pupuk majemuk dan mulsa organik. Pupuk organik dapat meningkatkan

\section{METODOLOGI PENELITIAN}

\section{Waktu dan Tempat}

Penelitianinidilaksanakan di Desa Tunggul Kecamatan Paciran Kabupaten Lamongan. Ketinggiantempat $\pm 5 \mathrm{~m}$ diatas permukaan laut. Waktu penelitian dilaksanakan pada bulan Pebruari sampai Mei 2020

\section{Bahan dan Alat}

Bahan yang digunakan dalam penelitian ini adalah : Benih Cabai Rawit varietas DEWATA, pupuk NPK Mutiara, pupuk kandang, mulsa jerami, mulsa sekam, dan pestisida untuk pengendalian hama dan penyakit. Alat yang digunakanadalah : cangkul, arit, pisau, gunting, timbangan, meteran, sprayer, dan alat-alat penunjang lainya.

\section{Pelaksanaan Penelitian}

Pengolahan lahan pada penelitian ini dilakukan dengan cara membajak atau mencangkul tanah untuk proses pembalikan tanah sehingga tanah bagian dalam terangkat kesuburan tanah dan kandungan unsur hara dalam tanah. Pupuk organik adalah pupuk yang tersusun dari materi makhluk hidup yang diolah melalui proses pembusukan oleh bakteri pengurai, seperti pelapukan sisa tanaman, hewan dan manusia (Sentana, 2010).

Selain pemupukan, penggunaan mulsa organik sangat di butuhkan untuk produksi tanaman cabai rawit, Pemberian mulsa organik memilki tujuan antara lain untuk melindungi tanaman, menjaga kelembaban tanah, eminimalisasi air hujan yang langsung jatuh ke permukaan tanah sehingga memperkecil erosi dan menjaga tekstur tanah. Bahan yang sering digunakan sebagai mulsa organik yaitu jerami padi, alang -alang, maupun sekam padi (Suhening, 2013).

kepermukaan. Setelah itu dilakukan proses penghalusan tanah agar diperoleh tanah yang gembur. Membuat petakan dengan tinggi 30 $\mathrm{cm}$, dan jarak $40 \mathrm{~cm}$, antar petak sehingga membujur (memanjang) dari arah utara ke selatan. Bertujuan agar penerimaan cahaya matahari terjadi secara merata keseluruh tanaman. Setelah itu di berikan pupuk bokashi dan juga kapur pertanian (Dolomit) sebagai pupuk dasar.

\section{Penyemaian Benih Cabai Rawit}

Penyemaian benih cabai rawit menggunakan dengan persemaian dosis yang menggunakan plastic panjang yang dipotongpotong. Kemudian menyiapkan campuran tanah, pupuk kandang dan kompos, dengan perbandingan 2:1:1, Tempat persemaian yang telah diisi media semai disusun dalam naungan tersebut. Benih cabai rawit direndam dengan air hangat selama kurang lebih 1 jam. Benih cabai rawit yang mengapung tidak digunakan. Setiap benih cabairawit dimasukkan kedalam tempat persemaian sedalam $0,5 \mathrm{~cm}$ dan ditutup dengan kompos halus. Kemudian dilakukan penyemprotan 
dengan air setiap pagi dan sore hari agar terjaga kondisi kelembapannya.

\section{Penanaman}

Penanaman dilakukan dengan cara ditugal sedalam $5 \mathrm{~cm}$ di tiap-tiap petak dengan terdapat jarak antar barisan $40 \mathrm{~cm}$ dan dalam barisan $40 \mathrm{~cm}$. Sehingga seluruh ruas guludan/bedengan memperoleh 20 tanaman

\section{Penyulaman}

Penyulaman dilakukan untuk mengganti bibit yang tidak tumbuh baik atau mati, kegiatan ini dilakukan untuk tanaman umur 7 hst.

\section{Pemupukan}

Pemupukan pupuk NPK menggunakan dosis $250 \mathrm{~kg} / \mathrm{ha}$, sedangkan pupuk kandang dengan dosis $20 \mathrm{t} / \mathrm{ha}$. Pemupukan NPK dan Pupuk Kandang diberikan7 hari setelah pengolahan lahan. setiap petak perlakuan mendapat suplai pupuk NPK sebanyak $0.08 \mathrm{~kg}$ dan pupuk kan dangan sebanyak $6.4 \mathrm{~kg}$.

\section{Penyiraman}

Tanaman cabai rawit membutuhkan air yang cukup, terutama di fase vegetatif (pertumbuhan dan perkembangan cabai rawit) sampai fase generatif. Penyiraman dilakukan pada pagi hari atau sore hari secara rutin. Apabila terjadi hujan maka tanaman cabai rawit tidak perlu disiram air.

\section{Penyiangan}

Penyiangan dilakukan pada waktu tanaman berumur 14 hari setelah tanam, tergantung pertumbuhan rumput dilahan. Penyiangan dilakukan mencabut rumput liar sekaligus dengan menggemburkannya.

\section{HASIL PENELITIAN}

\section{Tinggi Tanaman}

Hasil penelitian sidik ragam menunjukan adanya interaksi antara perlakuan macam pupuk majemukdan farietas terhadap tinggi tanaman pada pengamatan umur 14 hst, 28 hst, 42 hst. Rata-rata tinggi tanaman dapat di lihat dari tabel 1.

\section{Pemangkasan}

Pemangkasan tunas samping dilakukan pada tanaman cabai rawit yang berumur 14hari. Semua tunas samping dibuang agar tanaman tumbuh kuat dan kokoh, perempelan tunas ini dilakukan 2 kali, tanpa pemangkasan tunas samping pertumbuhan cabai rawit akan lambat. Daun-daun tua yang ada dibawah cabang dapat dirempel terutama daun yang terserang hama dan penyakit, daun tua tersebut sudah tidak produktif lagi.

\section{Pengendalian Hama Dan Penyakit}

Untuk menanggulangi hama dan penyakit secara menyeluruh dengan menggunakan prinsip pengendalian hama terpadu (PHT). Penerapan PHT harus dilakukan secara berkesinambungan. Penyemprotan pestisida dilakukan 7 hari sekali, penyemprotan dilakukan pagi hari atau sore hari, dan sebaiknya dilakukan sejak tanaman usia dini, supaya tanaman lebih tahan terhadap serangan hama dan penyakit.

\section{Pengamatan Dan Pengolahan Data}

Pengamatan produksi tanaman cabai rawit meliputi fase vegetatif (Tinggi Tanaman, Jumlah Cabang, Diameter Batang dan fase generatif (jumlah buah pertanaman, Berat Buah per Tanaman). Pengamatan dimulai saat tanaman berumur 14 hst dengan interval 14 hari sekali, sedangkan pengamatan fase generatif di lakukan setelah panen, Data hasil pengamatan dari setiap parameter pada setiap pengamatan dianalisa dengan Fhisher (uji F) $5 \%$ terdapat perbedaan nyata dilanjutkan dengan uji Beda Nyata Terkecil (BNT 5\%). 
Tabel 1. Rata-rata Tinggi Tanaman Cabai (cm) Pada Umur 28 dan 42 hst.

\begin{tabular}{llc}
\hline & \multicolumn{2}{c}{ Rata-rata tinggi tanaman $\begin{array}{c}\text { (cm) pada Pengamatan } \\
\text { Umur }\end{array}$} \\
\cline { 2 - 3 } & $\mathbf{2 8} \mathbf{~ h s t}$ & $\mathbf{4 2}$ hst \\
\hline Tanpa Pupuk Majemuk + Tanpa Mulsa & $21,86 \mathrm{de}$ & $36,43 \mathrm{c}$ \\
Tanpa Pupuk Majemuk + Mulsa Jerami & $19,49 \mathrm{e}$ & $38,18 \mathrm{bc}$ \\
Tanpa Pupuk Majemuk + Mulsa Sekam & $19,52 \mathrm{e}$ & $36,99 \mathrm{c}$ \\
Pupuk NPK + Tanpa Mulsa & $26,78 \mathrm{~b}$ & $38,58 \mathrm{bc}$ \\
Pupuk NPK + Mulsa Jerami & $30,26 \mathrm{a}$ & $44,43 \mathrm{a}$ \\
Pupuk NPK + Mulsa Sekam & $26,03 \mathrm{bc}$ & $39,87 \mathrm{~b}$ \\
Pupuk Kandag + Tanpa Mulsa & $23,61 \mathrm{bcd}$ & $37,61 \mathrm{bc}$ \\
Pupuk Kandang + Mulsa Jerami & $23,16 \mathrm{~cd}$ & $38,43 \mathrm{bc}$ \\
Pupuk Kandang + Mulsa Sekam & $26,31 \mathrm{~b}$ & $40,10 \mathrm{~b}$ \\
\hline \multicolumn{1}{c}{ BNT 5\% } & 3,4 & 2,85 \\
\hline
\end{tabular}

Pada Tabel 1 dapat dilihat bahwa penelitian paramet tinggi tanaman cabai rawit menunjukkan interaksi antara perlakuan pupuk majemuk dan mulsa organik. Nilai terbaik di tunjukkan oleh perlakuan pupuk majemuk NPK dan mulsa organik

\begin{abstract}
Diameter batang
Hasil dari pengukuran melalui skatemat menunjukan bahwa di detiap perlakukan ada perbedaan diameter batang pada pengamatan umur $14 \mathrm{hst}, 28 \mathrm{hst}, 42 \mathrm{hst}$. Dapat diihat dari tabel 2.
\end{abstract}

Tabel 2. Rata-rata Diameter Batang (cm) Pada Umur 28 dan 42 hst.

\begin{tabular}{lcc}
\hline & \multicolumn{2}{c}{$\begin{array}{c}\text { Rata-rata Diameter Batang (cm) pada } \\
\text { Pengamatan Umur }\end{array}$} \\
\cline { 2 - 3 } & $\mathbf{2 8} \mathbf{~ h s t}$ & $\mathbf{4 2} \mathbf{~ h s t}$ \\
\hline Tanpa Pupuk Majemuk + Tanpa Mulsa & 2,12 & 4,93 \\
Tanpa Pupuk Majemuk + Mulsa Jerami & 2,14 & 4,92 \\
Tanpa Pupuk Majemuk + Mulsa Sekam & 2,08 & 4,62 \\
Pupuk NPK + Tanpa Mulsa & 3,34 & 6,11 \\
Pupuk NPK + Mulsa Jerami & 3,89 & 6,49 \\
Pupuk NPK + Mulsa Sekam & 3,28 & 5,58 \\
Pupuk Kandag + Tanpa Mulsa & 2,72 & 4,66 \\
Pupuk Kandang + Mulsa Jerami & 3,51 & 5,86 \\
Pupuk Kandang + Mulsa Sekam & 3,24 & 6,46 \\
\hline \multicolumn{1}{c}{ BNT 5\% } & 0,2810 & 0,976 \\
\hline
\end{tabular}

Pada Tabel 2 dapat dilihat bahwa penelitian paramet Diameter Batang cabai rawit menunjukkan interaksi antara perlakuan pupuk majemuk dan mulsa organik. Nilai terbaik di tunjukkan oleh perlakuan pupuk majemuk NPK dan mulsa organic 


\section{Jumlah Cabang}

Hasil penelitian analisis jumlah cabang menunjukan bahwa terdapat interaksi antara perbedaan jarak waktu perlakuan pupuk majemuk dan mulsa organik pada tanaman cabai rawit terhadap jumlah cabang pada umur 24 hst dan 42 hst, perbedaan tersebut bisa di lihat dari tabel 3 jumlah cabang.

Tabel 3. Rata-rata Jumlah Cabang (cm) Pada Umur 28 dan 42 hst.

\begin{tabular}{|c|c|c|}
\hline \multirow[t]{2}{*}{ Perlakuan } & \multicolumn{2}{|c|}{$\begin{array}{l}\text { Rata-rata Jumlah Cabang pertanaman pada } \\
\text { Pengamatan Umur } 28 \text { dan } 42 \text { hst. }\end{array}$} \\
\hline & 28 hst & 42 hst \\
\hline Tanpa Pupuk Majemuk + Tanpa Mulsa & 10,27 & 22,43 \\
\hline Tanpa Pupuk Majemuk + Mulsa Jerami & 10,09 & 25,60 \\
\hline Tanpa Pupuk Majemuk + Mulsa Sekam & 10,35 & 24,47 \\
\hline Pupuk NPK + Tanpa Mulsa & 10,25 & 25,80 \\
\hline Pupuk NPK + Mulsa Jerami & 11,25 & 25,27 \\
\hline Pupuk NPK + Mulsa Sekam & 10,86 & 25,11 \\
\hline Pupuk Kandag + Tanpa Mulsa & 10,18 & 24,87 \\
\hline Pupuk Kandang + Mulsa Jerami & 10,23 & 24,80 \\
\hline Pupuk Kandang + Mulsa Sekam & 10,18 & 24,24 \\
\hline BNT 5\% & 0,548 & 1,588 \\
\hline
\end{tabular}

Pada Tabel 3 dapat dilihat bahwa penelitian paramet Jumlah Cabang cabai rawit menunjukkan interaksi antara perlakuan

\section{Jumlah Buah}

Hasil penelitian analisis jumlah batang menunjukan bahwa terdapat interaksi anta perbedaan jarak waktu perlakuan pupuk pupuk majemuk dan mulsa organik. Nilai terbaik di tunjukkan oleh perlakuan pupuk majemuk NPK dan mulsa organik majemuk dan mulsa organik pada tanaman cabai rawit terhadap jumlah batang pada umur 24 hst dan 42 hst, perbedaan tersebut bisa di lihat dari tabel 4 .

Tabel 4. Rata-rata jumlah buah Pada Umur 28 dan 42 hst.

\section{Perlakuan}

Rata-rata Jumlah buah pada Pengamatan Umur28 dan 42 hst.

\begin{tabular}{lcc} 
& 28 hst & $\mathbf{4 2}$ hst \\
\cline { 2 - 3 } Tanpa Pupuk Majemuk + Tanpa Mulsa & 9,8 & 12,00 \\
Tanpa Pupuk Majemuk + Mulsa Jerami & 8,8 & 13,77 \\
Tanpa Pupuk Majemuk + Mulsa Sekam & 11,5 & 15,20 \\
Pupuk NPK + Tanpa Mulsa & 10,3 & 13,60 \\
Pupuk NPK + Mulsa Jerami & 12,4 & 18,37 \\
Pupuk NPK + Mulsa Sekam & 10,2 & 14,23 \\
Pupuk Kandag + Tanpa Mulsa & 9,7 & 13,43 \\
Pupuk Kandang + Mulsa Jerami & 9,6 & 13,83 \\
Pupuk Kandang + Mulsa Sekam & 12,0 & 14,03 \\
\hline BNT 5\% & 1,5 & 1,33 \\
\hline
\end{tabular}


Dapat di lihat pada jumlah buah menunjukan bahwa pemberian macam pupuk majemuk dan mulsa organik terhadap pertumbuhan tanaman cabai rawit. Nilai tertinggi di

\section{Berat Buah}

Hasil analisa sidik ragam menunjukan bahwa di detiap perlakukan ada perbedaan Tabel 5. Rata-rata Berat Buah 82 hst tunjuukan pada perlakuan pupuk majemuk NPK dan mulsa organik jerami

Berat Buah pada pengamatan pertama fase generatif. Dapat di lihat dalam Tabel 5.

\begin{tabular}{lc}
\hline \multicolumn{1}{c}{ Perlakuan } & $\begin{array}{c}\text { Rata-rata Berat Buah pada } \\
\text { Pengamatan Pertama }\end{array}$ \\
\hline Tanpa perlakuan pupuk & $98,17 \mathrm{a}$ \\
Perlakuan pupuk NPK & $98,30 \mathrm{a}$ \\
Perlakuan pupuk kandang & $82,67 \mathrm{~b}$ \\
\hline BNT 5\% & 0,110 \\
\hline
\end{tabular}

Pada Tabel 10, dapat di lihat bahwa pada pengamatan ke dua terjadi perbedaan nyata antara waktu pelakuan pupuk majemuk dan mulsa organik pada tanaman cabai rawit.

\section{PEMBAHASAN}

Berdasarkan hasil analisis sidik ragam dan parameter pengamatan fase vegetatif meliputi tinggi tanaman dan jumlah cabang. Perlakukan pupuk NPK menunjukkan interaksi terhadap tinggi tanaman cabai rawit (tabel 1).

Menurut (widyanti dan Susilo, 2015) pemupukan $\mathrm{K}$ berpengaruh signifikan dengan pola linier terhadap tinggi tanaman dan Menurut Hulopi (2006) menyatakan bahwa pupuk NPK dapat meningkatkan pertumbuhan terutama tinggi tanaman, diduga karena peranan dari masing-masing pupuk $\mathrm{N}, \mathrm{P}$, dan $K$ yang dapat merangsang pertumbuhan vegetatif tanaman. Perbedaan tinggi tanaman cabai rawit ini di karenakan pupuk NPK lebih memiliki elemen tinggi terhadap tanaman sehingga berpengaruh pada tinggi tanaman, pada konsentrasi tersebut unsur hara yang dibutuhkan tanaman tersedia dalam keadaan tidak seimbang dan memicu peningkatan produksi tanaman cabai.

Menurut Prasetya M.E (2014) penggunaan pupuk majemuk NPK menjadikan
Berat buah pada perlakuan pupuk majemuk NPK lebih berat dibandingkan pada perlakuan pupuk kandang.

Perlakuan NPK dan mulsa jerami menghasilkan nilai yang lebih baik dibanding perlakuan lainya. Sedangkan terdapat hasil beda nyata dan sangat nyata pada perlakuan pupuk NPK terhadap diameter batang cabai rawit (tabel 2).

tanaman cabai banyak mengandung klorofil sehingga lebih hijau dan segar, batang menjadi kuat dan tegak, dapat mengurangi Resiko rebah menambah daya tahan tanaman terhadap gangguan hama, penyakit, dan kekeringan, memacu pertumbuhan akar dan sistem perakaran yang baik, memacu pembentukan bunga, memperbesar ukuran buah, umbi, dan biji-bijian mempercepat panen dan menambah kandungan protein, mengurangi resiko kerusakan selama pengangkutan dan penyimpanan, memperlancar proses pembentukan gula dan pati. Dan menurut (Sutrisna dan Yanto 2014) menyatakan bahwa pemberian $\mathrm{N}$ yang cukup, menjamin pertumbuhan yang baik, hasil panen yang lebih tinggi dan buah berkembang penuh 
Perlakuan pupuk NPK berpengaruh sangat nyata terhadap jumlah cabang pertanaman sampel (tabel 3). Hal ini di duga dari perlakuan pupuk NPK dan pupuk kandang memiliki perbedaan sifat atau karakter masing-masing sesuai dengan sifat genetiknya. Sehingga jumlah cabang tanaman cabai rawit yang di hasilkan berbeda jumlahnya. Nitrogen $(\mathrm{N})$ yang cukup selama pertumbuhan akan memberikan pertumbuhan tanaman yang baik, salah satunya adalah pertumbuhan batang tanaman (Sintia, M. 2011). Hal ini mengindentifikasikan bahwa semakin tinggi unsur hana nitrogen dibawah tanah maka kebutuhan tanaman cabai akan terpenuhi. Sehingga, pertumbuhan vegetatif tanaman cabai lebih baik Karena pada umumnya nitrogen diperlukan untuk pembentukan atau pertumbuhan bagian bagian vegetatif.

\section{KESIMPULAN DAN SARAN}

\section{Kesimpulan}

Berdasarkan hasil penelitian yang telah di lakukan dengan perlakuan pupuk majemuk dan mulsa organik terhadap pertumbuhan tanaman cabai rawit dapat di simpulkan bahwa:

Menunjukkan interaksi antara perlakuan pupuk majemuk dan mulsa organik terhadap pertumbuhan tanaman cabai rawit pada parameter tinggi tanaman, diameter batang dan jumlah cabang pada fase vegetatif

\section{DAFTAR PUSTAKA}

Diaz-Perez, J.C., K. D. Batal, 2002. Mulsa isi plastik berwarna mempengaruhi pertumbuhan dan hasil tomat melalui perubahan suhu zona akar. J. Amer. Soc. Hort. Sci. 127 (1): 127-13.

Hulopi,F. 2006. Pengaruh penggunaan pupuk kandang dan pupuk NPK terhadap pertumbuhan dan hasil tanaman kacang tanah buana sains 6(2):165-170.
Perlakuan pupuk NPK dan mulsa jerami menunjukkan pertumbuhan yang sangat baik terhadap parameter pengamatan tinggi tanaman dimeter cabang, jumlah cabang, jumlah buah dan berat buah. Sehingga, akan mendukung untuk menghasilkan jumlah buah dan berat buah pada tanaman cabai rawit. Suhu tanah di daerah perakaran penting untuk pertumbuhan dan perkembangan tanaman karena mempengaruhi proses fisiologi di dalam akar tanaman seperti pengambilan air dan nutrisi mineral dari tanah (Diaz-Perez dan Batal 2002). Seperti yang dikemukakan oleh Sutejo (2002), unsur P berfungsi sebagai salah satu unsur penyusun protein yang dibutuhkan untuk pembentukan bunga, buah dan biji.

Menunjukkan pengaruh nyata padaperlakuan pupuk majemuk dan mulsa organik terhadap pertumbuhan tanaman cabai rawit, jumlah buah pada fase generatif

Perlakuan varietas cabai rawit Dewata perlakuan pupuk majemuk NPK dan mulsa organik jerami menghasilkan nilai yang lebih baik dibandingkan perlakuan lainnya.

\section{Saran}

Penelitian ini dapat dilanjutkan dengan perlakuan macam varietas dan jarak tanam atau perlakuan lainnya dilahan pertanian untuk lokasi yang berbeda, sehingga dapat mengetahui hasil yang lebih baik lagi.

Prasetya, M.E. 2014. Pengaruh pupuk NPK mutiara dan pupuk kandag sapi terhadap pertubuhan dan hasil tanaman cabai merah kriting varietas Arimbi. Jurnal AGRIFOR, Vol.XIII no:,oktober 2014, hal.191-198.

Sentana, S., (2010). Pengembangan dan pengujian inokulum untuk pengomposan limbah tandan kosong kelapa sawit. Jurnal Rekayasa Proses, 4(2), 35-39. 
Sintia, M. 2011 pengaruh beberapa dosis kompos jerami padi dan pupuk nitrogen terhadap pertumbuhan dan hasil jagng manis (zeamays saccharata sturt) Jurnal Tanaman Pangan (1):1-7.

Sutejo, M. 2002 Pupuk Dan Cara Pemupukan. Rinika cipta, Jakarta.
Sutrisna dan Yanto (2014) Uji Formula NPK pada pertanaman cabai rawit dataran tinggi Lembang, Jawa Barat. Agros 16(1):172_181.

Widyanti, dan susila. 2015 rekomendasi pemupukan kalium pada budidaya cabai merah besar (capsicum annum L.) di inceptisols Dramaga J. Hort. Indonesia. 6(2): 65-74. 